\title{
Iranian EFL Teachers' Sense of Professional Identity and their Computer Literacy
}

\author{
Toktam Abtahi (Corresponding author) \\ English Department, Torbat-e-Heydarieh Branch, Islamic Azad University, Torbat-e-Heydarieh, Iran \\ E-mail:toktamabtahi@gmail.com \\ Khalil Motallebzadeh \\ English Department, Torbat-e-Heydarieh Branch, Islamic Azad University, Torbat-e-Heydarieh, Iran \\ E-mail:kmotallebz@gmail.com
}

\author{
Received: 02-10-2015 \\ Accepted: 01-01-2016 \\ Advance Access Published: January 2016 \\ Published: 01-03-2016 \\ doi:10.7575/aiac.ijalel.v.5n.2p.207 \\ URL: http://dx.doi.org/10.7575/aiac.ijalel.v.5n.2p.207
}

\begin{abstract}
This study examines Iranian EFL teachers' sense of professional identity and their computer literacy. To these end, 718 EFL teachers from different cities in Iran filled out job satisfaction, occupational commitment, and computer literacy questionnaires. SPSS software was employed to summarize the collected data. Independent Sample t-test and Pearson Product-Moment Correlation were run to check the level of significance. For qualitative data collection, five openended questions were added to the end of the job satisfaction questionnaire. The obtained answers were categorized and the frequency for each category was calculated. The results revealed that computer literacy has a significant relation with continuance commitment, job satisfaction, and gender. The results further suggested that teacher computer literacy provided an encouraging base for their professional identity.
\end{abstract}

Keywords: Teachers' sense of professional identity, Occupational commitment, Job satisfaction, Computer literacy, Teachers' computer literacy

\section{Introduction}

Over the last century, professionalism has been the subject of numerous studies (Day, 2002). Day (1999) defined teachers as the heart of the process of education. Verghase (2010) pointed out though some scholars (Moran, 1996; Duff \& Uchida, 1997; Johnston, 1997) investigated ESL, bilingual, and foreign language teachers' professional identities, they have never been considered as a subtopic within the field of language teacher education. Johnston (1997) argued that though the notion of career and profession are extremely prevalent in discussions of EFL/ESL teaching, little is known about the teacher's working lives in this area. Day (2002) in his argument about professionalism, mentioned the importance of considering teachers' identities, the role of self-efficacy, motivation, job satisfaction and commitment and the relationship between these and being effective.

Hall (1999, in Vesanto, 2011) indicated that identity as incomplete concept has had continuous and unconscious growth over time. It is maintained that "teachers' perceptions of their own professional identity affect their efficacy and professional development as well as their ability and willingness to cope with educational change and to implement innovations" in their own practice about teaching (Beijaard, Verloop, \& Vermunt, 2000, p.750).

Motallebzadeh (2005) stated that everyone is entitled to an opportunity in order to become more and more dynamic in a constantly changing world within which the people live with the newest data. Without exception, the language teachers are needed to access information in order to perform their responsibilities more successfully. He also argued that change is a prerequisite for ICT use in educational environment. As a result, a key issue in the area of teacher education is how to develop the ability of using computers (Son, 2004).

Toffler (1984, in Miller \& Green, 2012) claimed that change is life- not just necessary to life. A crucial aspect of teachers' professional identity is change. One of the factors that can affect that change is their awareness and their ability on the new world of technology. As agents of change, if teacher become ICT literate, they would make a lot of positive attitude to computer use and information technologies (Kpai, Joe-Kinanee, \& Ekeleme, 2012). An important rationale behind the ICT's failure in teaching is teacher resistance to ICT. It is argued that difficulties are the consequences of the lack of training. Many teachers feel uncomfortable since they do not have both the necessary IT abilities and the specific training to use the new resources in the classroom environment (Carnoy, 2004).

The interrelationship between variables of the current study is not very much investigated in Iran. Therefore, the result of this study will be helpful for teachers, students, and educational settings.

To address the aforementioned problem, the question arises as follow: 
Q1: Is there any significant relationship between Iranian EFL teachers' sense of professional identity and their computer literacy?

Q2: Is there any significant relationship between Iranian EFL teachers' computer literacy and their gender?

To avoid subjectivity, the researcher presented the following null hypotheses.

H01: There is no significant relationship between Iranian EFL teachers' sense of professional identity and their computer literacy.

H02: There is no significant relationship between Iranian EFL teachers' computer literacy and their gender.

\section{Literature review}

An emerging field of research in education is investigating teacher professional identity. Though, the notion of professional identity has been explored in the English language teaching environment, it not as widely as other educational setting (Fraser, 2011). Within a rapidly changing global society, teachers are experiencing their roles and recreating their professional identities in relation to the surrounding environment, sometimes changing in unexpected ways (Haamer, Lepp, \& Reva, 2012).

One of the crucial segments that directly influence the quality of language education is the identity of language teacher. Teacher identity embodies the aspects which the society designates to the teacher profession and those which individual teachers ascribe to it. Constant changes in the education system compel teachers to promote specific abilities and reform their role in the process of teaching (Kašelionyte, 2010).

The presence of technological devices in teaching and learning has opened up a whole new world of investigation into the issue of effective teaching (Rahimi \& Yadollahi, 2011). The capacity of technology to generate opportunities for powerful teaching and learning setting is supported in many studies. Knezek and Christensen (2002) explained that new information technologies have vital impact on teachers and students. Scholars discover that adaption of technology can impact learning of a foreign language (cf. LeLoup \&Ponterio, 2005), and students' learning (O'Connell, Freed, \& Rothberg, 2010). Gilakjani and Leong (2012) noted that a good deal of current studies (e.g. Becker et al., 1999) have shown that teachers integrate technology devices more readily when they have a strong commitment to teaching and their own professional growth.

\subsection{Professional identity}

Recently, the notion of professional identity has attracted interest in various fields of study. According to Ibarra (1999) professional identity is an individual's professional self-concept based on the set of values, attributes, beliefs, motives, and experiences. Within the area of teaching and teacher education, numerous studies have focused on teachers' sense of their professional identity (Canrinus, Helms-Lorenz, Beijaard, Buitink, \& Hofman, 2011). Day (2002, in Canrinus, 2011) maintained that teachers' professional identity is shown in teachers' job satisfaction, teachers' occupational commitment, and self-efficacy and changing in motivation level. A perception of teachers' sense of their professional identity can be obtained by assessment of these four constitutes within a personal and contextual variables framework (Canrinus, 2011). Scholars emphasize the importance of reviewing the influential factors in individuals' job satisfaction and organizational commitment within the information technology (IT) environment due to the fact that working market in the field of IT trends to provide career opportunities for IT specialists worldwide (Lumley, Coetzee, Tladinyane, \& Ferreira, 2011).

\subsection{Job satisfaction}

Nasir (2011) indicated that job satisfaction is the perceived benefits, by teachers, who expect from their career and the degree to which they believe they have accomplished these benefits. According to Landsman (2001, in Canrinus, Helms-Lorenz, Beijaard, Buitink, \& Hofman, 2012) job satisfaction positively affects occupational commitment. Moreover, the employees' job satisfaction significantly predicted the employees' occupational commitment. According to this idea, Canrinus et al. (2012) assumed that teachers' job satisfaction is a contributing factor in teachers' occupational commitment. Ololube (2006) maintained that job satisfaction and motivation relevance are very important to the long-term development of any educational system in the world.

\subsection{Occupational commitment}

Occupation was considered as the individuals' employment in a certain time in an identified work to make money for the maintenance of their living activities (Lee \& Allen, 2000, in Ciftcioglu, 2011).

In 1984, Meyer and Allen suggested affective and continuance commitment with the former connoting emotional attach to, identify with, and involve in the organization and with the latter connoting the perceived costs associated with leaving the organization. Allen and Meyer (1990) later suggested normative commitment as the third component, which shows a perceived obligation to stay in the organization (cited in Meyer, Stanley, Herscovitch, \& Topolnytsky, 2002). Due to the fact that a group of work-related phenomenon over an individual's lifespan can be interpreted as career, Meyer, Allen, and Smith (1993) chose occupational commitment instead of career commitment to avoid confusion.

\subsection{Computer literacy}

According to the International ICT Literacy Panel (2007), the prominence of technology is increasing in people's everyday lives and this presence will definitely expand hereof. Richards and Schmidt defined computer literacy as "having sufficient knowledge and skill in the use of computers and computer software to be able to live in a computer- 
orientated society" (2002, p.102). Computer literacy is defined as the skill to use computers at an adequate level to create, communicate and collaborate in a literate community. Computer literacy includes the improvement of knowledge and abilities for using general computer devices, software programs and Internet tools totally and confidently in education for language teaching (Son, Robb, \& Charismiadji, 2011).

Teachers' computer literacy and competency in online settings have been discussed in a number of researches as an important factor (Son et al., 2011; Park \& Son, 2009). Son et al. (2011) argued that the expanding use of electronic texts has extended the meaning of the word literacy and raised new literacies such as computer, electronic and information literacies since computer technology becomes widely available and quickly developed. Furthermore, extensive studies on the actual level of language teachers' computer literacy and competency in local context are required due to the need for language teacher development in e-literacy (Son et al., 2011).

The fact that the application of computer can improve foreign and second language learning is supported in almost all research which is conducted on CALL effectiveness (Warschauer \& Healey, 1998; Saleh Mahdi, 2014). Rahimi and Yadollahi (2011) explain that for this purpose, understanding EFL teachers' characteristics and their relationship with ICT use appear to be of primary importance to contribute to effective teaching and learning in CALL setting.

Some of the current studies have investigated professional identity and computer literacy. Son (2004) suggested that computer-mediated communication (CMC) can effectively enhance teacher improvement through communication, professional collaboration and critical reflection in local contexts. He argued that improvement of competencies in elearning context is a crucial task for teachers. Son et al. (2011) examined the level of computer literacy of a group of EFL Indonesian teachers and investigated factors affecting their computers use. According to the results, they recommend increasing the teachers' online opportunities, competencies and skills in computers use for their teaching practices and professional development.

Alabi and Yisa (2013) investigated the influence of computer literacy on teacher job effectiveness and they found a significant relationship. They argued that computer application software should be employed by teachers in order to improve teaching and learning, student learning, and their own professional growth. Gilakjani and Leong (2012) stated that some studies (e.g. Hadley \& Sheingold, 1993) have indicated that teachers integrate technology devices more readily when they have a strong commitment to teaching and their own professional development. Some studies reveal that computer literacy and job effectiveness are related to each other (Akinnubi, OzoveheSule, \& Yisa, 2012; Alabi \& Yisa, 2013).

In a study about gender differences in computer attitudes, literacy, locus of control, and commitment, it is revealed that males' scores on the subscales of computer literacy and commitment to computers were significantly higher than female. Accordingly, efforts for imparting computer literacy skills to female student teachers are recommended (Kay, 1989). In another study of computer literacy among trainee teachers, Kpai et al. (2012) maintained that the level of computer literacy amongst trainee teachers especially among fresh students was generally low. The male trainee teachers found more adapted at skills and literacy in ICT than their female co-workers.

\section{Methodology}

\subsection{Participants}

Iranian EFL teachers ( $\mathrm{N}=718,268$ males and 450 females) who had taught in private sectors in Iran participated in this study. According to a recent census results announced by Statistical Center of Iran (2011), the most populous cities in Iran with a population of more than 1,000,000 are as follow: Tehran (8.2 million), Mashhad (2.7 million), Isfahan (1.7 million), Karaj (1.6 million), Tabriz (1.49 million), Shiraz (1.46 million), Ahvaz (1.1 million), and Qom (1 million).

The data collection was based on the assumption that there are 400 private sectors in Tehran and 700 in the other aforementioned cities.

The calculation have done based on the assumption that the whole numbers of English Language private sectors in Iran are 3,050 and each institute has an average of 10-40 teachers. Consequently, this study's society was embraced the whole number of 76,375 English language teachers (Table 1).

Table 1. The assumption of private sectors in Iran based on a recent census results announced by Statistical Center of Iran Population (2011)

\begin{tabular}{llllll}
\hline City(es) & Population & $\begin{array}{l}\text { Assumed no. of } \\
\text { sectors in each } \\
\text { city }\end{array}$ & Total no. & $\begin{array}{l}\text { No. of teachers } \\
\text { in each institute }\end{array}$ & $\begin{array}{l}\text { Total no. of } \\
\text { teachers }\end{array}$ \\
\hline Tehran & 8.2 & 400 & 400 & 40 & 16,000 \\
$7 *$ & bet.1,000,000-3,000,000 & 100 & 700 & 35 & 24,500 \\
7 & bet. $500,000-1,000,000$ & 30 & 210 & 30 & 6,300 \\
71 & bet.100,00-500.000 & 15 & 1,065 & 20 & 21,300 \\
81 & bet. 50,000-100,000 & 5 & 405 & 15 & 6,075 \\
135 & bet. 20,000-50,000 & 2 & 270 & 10 & 2,700 \\
$302^{* *}$ & & & 3,050 & & 76,375 \\
\hline
\end{tabular}

*Total population of 7 major cities of Iran which are: Mashhad, Isfahan, Karaj, Tabriz, Shiraz, Ahvaz, and Qom is 11.05 million.

** The total number of cities over 20,000 populations. 
In this study by estimating the probable limitation and problems, the society of 75,000 was chosen. According to Krejcie and Morgans' table (1970) the required sample of participants in the study was 658 teachers (regarding to the $99 \%$ level of confidence and 0.05 degree of accuracy). The researcher sent the survey invitation to 2790 participants online. The participants who filled out the online format worked in institutes (551), universities and educational ministry.

The survey invitation was sent to 2790 participants online. 551 teachers filled out the online format. According to the assumption that the participants who filled out the questionnaire online, have the knowledge of using computer, 450 questionnaires were delivered in paper to different institutes in Tehran and Mashhad. Out of 196 questionnaires send back, 29 questionnaires were excluded during data reviewing. Consequently, the data analyses were conducted based on the available data from 718 participants who filled out the online (551) and the paper format (196). These participants were considered as professional experienced teachers having university education. They were both males and females, from different age groups, and different years of experiences whose native language was Farsi. Their field of study was English language teaching, English literature, translation, and other. All of them were supposed to pass the TTC program whether in University or Institute.

\subsection{Procedure and instruments}

The required data collected online using Google Forms and in paper from all available subjects during fall semester 2014. Teachers were asked to fill out the questionnaires and give some biographical data as follows: gender, age, academic degree, years of experience, place of work, field of study, and the city that they were teaching. The anonymity of the participants and confidentiality of their answers in all phases of the research were considered. After collecting the data, it was entered into and processed with SPSS 22 program. To this end and based on the collected data, mean, standard deviation, independent sample t-test and Pearson Product-Moment Correlation were used to analyze the obtained data and also to check whether the results were significant or not. In addition, five open-ended questions were analyzed in order to check the EFL teachers' job satisfaction. To collect the data, these questionnaires were used:

\subsubsection{Computer literacy questionnaire}

This questionnaire (Jenkins, Mimbs, Kitchel, 2008) consisted of 7 items on a 6-point Likert scale ranging from strongly disagree to strongly agree. Jenkins, et al. (2008) determined the questionnaire face and content validity by using a panel of experts. Then, they used a pilot group $(n=30)$ to determine the research reliability. Using Cronbach's alpha, they found a reliable coefficient of 0.77 for computer literacy.

3.2.2 Teachers' sense of professional identity

According to Day (2002, in Canrinus, 2011) manifestation of professional identity coincides with: satisfaction with job, commitment to occupation, self-efficacy, and motivation. In this research, professional identity limited to teachers' job satisfaction and occupational commitment.

\subsubsection{Occupational commitment questionnaire}

Meyer et al.'s (1993) 18-items occupational commitment (affective, continuance and normative) embodies six items in each scale. Five items negatively phrased and reversed scored. Responses to these items were on 7-point Likert scale ranging from strongly disagrees to strongly agree. In Bagraim (2003) the coefficient alphas for affective, continuance and normative commitment were $0.79,0.85$, and 0.82 .

\subsubsection{Teachers' job satisfaction scale}

This questionnaire consisted of 30 items which measures extrinsic and intrinsic satisfaction on a 5-point Likert scale that ranked from strongly agree (5) to strongly disagree (1). Extrinsic satisfaction includes 25 items in six subcategories which are: career, economic, professional growth, social, work environment, and management factors, while intrinsic satisfaction includes 5 items. The overall Reliability Coefficient $(\alpha)$ of total items was 0.90 (Nasir, 2011).

\subsubsection{Interview / Open ended questions}

For the qualitative data collection five open-ended questions were included at the end of the job satisfaction questionnaire. The time allotted for answering the questions was about 5-6 minutes. Twenty teachers attended interview. To sum up, 157 EFL teachers answered the open ended questionnaire, 46 in papers, 91 online, and 20 in the interview. The responses were analyzed and 12 of them were excluded. Thus, the total number of 145 EFL teachers participated in this part. The questions about job satisfaction were as follows:

- What are the two reasons that make you satisfied with your job?

- If you going to criticize your own job, what are the reasons that make you dissatisfied with your job?

- What steps do you think may increase the satisfaction level of teachers?

- Are you satisfied with the existing pay scale and financial package for teachers? If "No" why?

- Any other comments/suggestions. (Regarding recruitment of teachers, terms and conditions, facilities, etc.)

\section{Results and Discussion}

\section{Quantitative data}

Q1: Is there any significant relationship between Iranian EFL teachers' sense of professional identity and their computer literacy? 
In order to answer this research question, Pearson Product-Moment Formula was used. Results can be seen in Table 2.

Table 2. Correlation

\begin{tabular}{llllllll}
\hline Computer & Pearson & Computer & Affective & Continuance & Normative & JS & JS \\
Literacy & Correlation & Literacy & Commitment & Commitment & Commitment & Intrinsic & Extrinsic \\
\cline { 2 - 8 } & Sig.(2-tailed) & 1 & -.058 & $.125^{* *}$ & .070 & $.268^{* *}$ & $.203^{* *}$ \\
& $\mathrm{~N}$ & & .119 & .001 & .061 & .000 & .000 \\
& & 718 & 718 & 718 & 714 & 718 & 714 \\
\hline
\end{tabular}

As Table 2 shows, some significant relations were found between subscales of Iranian EFL teachers' sense of professional identity and their computer literacy. Computer literacy scale is significantly and positively related to continuance commitment $(\mathrm{r}=0.12, \mathrm{p}<0.05)$. In other words, the higher the teachers' computer literacy, the higher is their continuance commitment. Moreover, computer literacy was positively and significantly related to intrinsic factors $(\mathrm{r}=0.26, \mathrm{p}<0.05)$ and extrinsic factors $(\mathrm{r}=0.20, \mathrm{p}<0.05)$. No significant correlations were found between computer literacy with affective and normative commitment.

Q2: Is there any significant relationship between Iranian EFL teachers' computer literacy and their gender?

In order to answer this research question, independent-samples t-test was run. Descriptive statistics can be seen both for males and females in Table 3.

Table 3. Group statistics

\begin{tabular}{lllllll}
\hline & Gender & & $\mathrm{N}$ & Mean & Std. Deviation & Std. Error Mean \\
\hline Computer & dimensional & male & 268 & 32.63 & 4.37 & 0.26 \\
Literacy & & female & 450 & 30.53 & 4.98 & 0.23 \\
\hline
\end{tabular}

As Table 3 indicates, mean of the computer literacy for males is 32.63 and for females is 30.53 . To see whether these differences are statistically significant, t-test was conducted.

Table 4. Independent samples test

\begin{tabular}{|c|c|c|c|c|c|c|c|}
\hline \multirow{4}{*}{$\begin{array}{l}\text { Computer } \\
\text { literacy }\end{array}$} & \multirow[b]{3}{*}{ Equal variances assumed } & \multicolumn{6}{|c|}{ Levene's Test for } \\
\hline & & $\mathrm{F}$ & Sig. & $\mathrm{t}$ & df & $\begin{array}{l}\text { Sig. } \\
\text { (2-tailed) }\end{array}$ & $\begin{array}{l}\text { Mean } \\
\text { Difference }\end{array}$ \\
\hline & & .212 & .646 & 5.714 & 716 & .000 & 2.10 \\
\hline & Equal variances not assumed & & & 5.902 & 618.504 & .000 & 2.10 \\
\hline
\end{tabular}

First, based on Levene's test appropriate df and t were selected. As Table 4 shows, there is a statistically significant difference between males and females with regard to computer literacy $t(716)=5.71, p<0.05$. As the mean of the males is higher than that of the females, it can be concluded that males have a higher computer literacy than females.

\section{Qualitative data}

Five open-ended questions were included at the end of the job satisfaction questionnaire. The total number of $145 \mathrm{EFL}$ teachers' responses were analyzed in this part. Analysis of qualitative data related to open-ended questions and interview was conducted through step by step process. The raw information were converted into frequencies and placed in identical categories of responses. Once the analysis of the responses finished, the researcher grouped the obtained answers into different categories to make the data quantifiable. Wherever required, results were presented in tables and additionally frequencies of the opinions of the participants were calculated into percentage.

The purpose of the first question was to check the EFL teachers' reasons that make them satisfied with their job.

The reasons of job satisfaction were: like teaching itself $(34.5 \%$; e.g. the rewarding nature of work; sharing the knowledge), the students (24.1\%; e.g. they liked their students and working with them); social factors (20.7\%; e.g. social communication, their colleagues, warm and friendly context); self development (9.0\%; e.g. learning through the procedure of teaching); English itself (6.2\%; e.g. speaking in English); and time-management (5.5\%).

Second, reasons for job dissatisfaction were: salary (39.3\%; low salary comparing to work hours for instance); work environment (28.3\%; e.g. strict and traditional rules, lack of facilities); job insecurity (17.2\%; e.g. insurance); professional growth (15.2\%; e.g. lack of promotion chance).

Third, steps that could increase teachers' job satisfaction. The participants' responses $(\mathrm{N}=135)$ to this question were considered as six factors. The steps included: economic factors (e.g. increasing salary due to inflation; 26.7\%); career factors (e.g. autonomy, security; 20.75\%); management factor (e.g. appreciation and acknowledging teachers effort and capability; 16.3\%); professional growth factors (e.g. purposeful in-service training courses; 14.1\%); work environment (e.g. providing useful and enough facilities; 13.3\%); social factors (e.g. friendly working atmosphere; 8.9\%).

Fourth, whether or not teachers are satisfied with their pay scale and fanatical package. Out of total number of 
participants $(\mathrm{N}=135)$ who answered this item, the majority $(94.1 \%)$ were dissatisfied with their payment for various reasons.

Finally, the last item concentrated on teachers' suggestion and comments. The participant suggestions were grouped in five categories. Out of 145 participants who answered the open-ended and interview questions, 46 participants answered this question. Teachers' suggestion and comments were: professional growth opportunities (e.g. TTC courses and workshop; 34.8\%); work environment conditions (e.g. classroom facilities; 23.9\%); the government role (e.g. raising the standard for teachers' graduation in the university; 21.7\%); pay more attention to education and support young teachers to start teaching profession (15.2\%); considering other factors such as educational degree and qualification for salary $(4.3 \%)$.

\section{Conclusion}

Having analyzed the collected data it was revealed that computer literacy scale is positively and significantly related to continuance commitment, intrinsic and extrinsic factors of job satisfaction. No significant correlations were found between computer literacy, affective and normative commitment.

The relationship between computer literacy and extrinsic and intrinsic factors of job satisfaction (pay, promotion, supervision, co-workers, etc) suggested that improving the levels of teacher job satisfaction could increase teachers' computer literacy, and vice versa.

Regarding to the second research question, a substantial difference was found between males and females with regard to computer literacy. The result showed that males have a higher computer literacy than females.

There aren't studies that examined the relationship between teachers' sense of professional identity and their computer literacy to the best knowledge of the researchers. Some scholars investigated the relationship between computer literacy and teacher job effectiveness. Alabi and Yisa (2013) investigated the influence of computer literacy on teacher job effectiveness and they found a significant relationship between teachers' computer literacy and job effectiveness. This is in accordance with Akinnubi et al (2012) which indicated a significant relationship between computer literacy and teacher job effectiveness.

The result revealed that males have a higher computer literacy than females. This finding confirms Kay's (1989) in that males' scores on the subscales of computer literacy and commitment to computers were significantly higher than female. This is in agreement with the ideas of Kpai et al. (2012) who have declared that the male trainee teachers feel adapted at skills and literacy in ICT more than their female co-workers. On the contrary, Woodrow (1992) examined the change in computers' knowledge and attitudes toward computers among pre-service teachers. The result indicated no gender effects.

To sum up, since males demonstrated a higher computer literacy than females, it would be helpful to provide more opportunity for female in order to increase their computer literacy. It would be necessary to offer them opportunities to use various kinds of applications if their self-confidence in the use of different types of computer-based activities needs to be improved.

To summarize the results of the analysis of the qualitative data in the current study, the researcher puts emphasis on five outstanding outcomes which are as follows: reasons of teachers' job satisfaction/ dissatisfaction, steps for increasing teachers' job satisfaction, satisfaction with payment and fanatical package, and teachers' suggestion. Accordingly, economic, career, management, environment, social, and professional growth factors were introduced as factors that might increase the teachers' job satisfaction. This is in accordance with Nasir's (2011) study which confirmed that the majority of the teachers were dissatisfied with their payment and financial package. Ololube (2006) found the same reasons for teachers' job dissatisfaction, for instance the educational policies and administration, payment, and fringe benefits.

\subsection{Pedagogical implications}

The findings of this study can have direct or indirect implications for teachers' training, syllabus designing, material producing, programming, teaching and learning context. The outcomes can also increase EFL teachers' understanding of the effect of computer literacy on the development of professional identity. The results may provide hints for headmasters who manage goals and decisions of the institutes and are able to provide opportunity for teachers' professional growth.

Almost all research conducted in CALL effectiveness(e.g. Warschauer \& Healey, 1998) supported the application of computer in order to improve foreign and second language learning. For that reason, computer literate teachers can help the learners more effectively. This study suggests instructors to transform their approach in teaching and learning processes, and move from strict rules and procedures to a flexible working environment in which the power and authority are shared between the teachers and the headmasters. Furthermore, this study offers the headmasters to make an effort to develop teachers' job satisfaction. Thus, to develop computer literacy in educational system and to make computer sensible in teaching and learning process, not only language teachers but also private sectors, universities, and the Ministry of Education should make preparations for a suitable environment in which every attempt is made to promote the individuals' computer literacy and to practice computer use in every subject area.

\subsection{Suggestions for further research}

Additional researches can be carried out on the following areas that have not been considered by the researcher in 
EFL/ESL context. It would be great to examine the relationship between teachers':

- Occupational commitment and job satisfaction in EFL context.

- Sense of professional identity, access, and use of technology

- Computer literacy, access and use of technology

- Computer literacy and other variables such as age, academic degree, teaching experience, and work context.

\section{Acknowledgements}

Accomplishing this study, we would like to thank all those who have helped us with, the supervisors and teachers who graciously volunteered their time to participate in this project.

\section{References}

Akinnubi, O. P., OzoveheSule, A., \& Yisa, H. (2012). Computer Literacy and Teacher Job Effectiveness in Kwara State Secondary Schools. Academic Reserch International, 2(3), 329-333.

Alabi, A.T., \&. Yisa, H. M. (2013). Computer literacy and teacher job effectiveness among secondary school teachers in Ilorin South Local Government Area, Kwara State, Nigeria. Nigeria Educational Forum, A Journal of the Institute of Education, Ahmadu Bello University, 21(1), 63-72.

Bagraim, J. J. (2003). The dimensionality of professional commitment. SA Journal of Industrial Psychology, 29(2), p. 69.

Beijaard, D., Verloop, N., and Vermunt, J. D. (2000). Teachers‘ perceptions of professional identity: An exploratory study from a personal knowledge perspective. Teaching and Teacher education, 16, 749-764.

Canrinus, E. T. (2011). Teachers' sense of their professional identity (Doctoral dissertation). University of Groningen.

Canrinus, E. T., Helms-Lorenz, M., Beijaard, D., Buitink, J., \& Hofman, A. (2012). Self-efficacy, job satisfaction, motivation and commitment: Exploring the relationships between indicators of teachers' professional identity. European journal of psychology of education, 27(1), 115-132.

Canrinus, E. T., Helms $\square$ Lorenz, M., Beijaard, D., Buitink, J., \& Hofman, A. (2011). Profiling teachers' sense of professional identity. Educational Studies, 37(5), 593-608.

Carnoy, M. (2004). ICT in education: Possibilities and challenges. Inaugural Lecture of the UOC 2004-2005, Barcelona

Ciftcioglu, A. (2011). Investigating Occupational Commitment and Turnover Intention Relationship with Burnout Syndrome. Business and Economics Research Journal, 2(3), 109-119.

Day, C. (1999). Developing teachers: The challenges of lifelong learning. London, Philadelphia: Falmer Press.

Day, C. (2002). School reform and transitions in teacher professionalism and identity. International journal of educational research, 37(8), 677-692.

Duff, P. A., \& Uchida, Y. (1997). The negotiation of teachers' sociocultural identities and practices in postsecondary ESL classrooms. TESOL Quarterly, 31, (3), 451-486.

Fraser, M. (2011). Exploring the nature and process of professional identity of teachers of English in Japanese higher education (Doctoral dissertation). Faculty of Education, University of Wollongong, New South Wales, Astralia.

Gilakjani, A. P., \& Leong, L. M. (2012). EFL Teachers' Attitudes toward Using Computer Technology in English Language Teaching. Theory and Practice in Language Studies, 2(3), 630-636.

Haamer, A., Lepp, L., \& Reva, E. (2012). The dynamics of professional identity of university teachers: Reflecting on the ideal university teacher. Studies for the Learning Society, 2(2-3), 110-120.

Ibarra, H. (1999). Provisional selves: Experimenting with image and identity in professional adaptation. Administrative Science Quarterly, 44(4), 764-791.

International ICT Literacy Panel (2007). Digital transformation: A framework for ICT literacy. Washington, DC: Educational Testing Service (ETS).

Jenkins, D., Mimbs, C.A., \& Kitchel, T. (2008). Computer literacy, access, and use of technology in the Family and Consumer Sciences classroom. Journal of Family and Consumer Sciences Education, 27(1), 1-13. Available at http://www.natefacs.org/JFCSE/v27no1/v27no1Jenkins.pdf

Johnston, B. (1997). Do EFL teachers have careers? TESOL Quarterly, 31(4), 681-712.

Kašelionyte, J. (2010). Shaping and reshaping the professional self. Vilnius University, Lithuania, Verbum, (1), 85-94.

Kay, R. H. (1989). Gender differences in computer attitudes, literacy, locus of control and commitment. Journal of Research on Computing in Education, 21(3), 307-316.

Knezek, G., \& Christensen, R. (2002). Impact of new information technologies on teachers and students. Education and Information Technologies, 7(4), 369-376. 
Kpai, T., Joe-Kinanee, J. N., \& Ekeleme, C. (2012). A study of computer literacy among trainee teachers in a Nigerian university of education. Global Voice of Educators, 1(1), 1-7.

Krejcie, R. L., \& Morgan, D. W. (1970). Determining sample size for research activities. Educational and Psychological Measurement, 30, 607-610.

LeLoup, J. W., \& Ponterio, R. (2005). Technology and Foreign Language Instruction: Where We Have Been, Where We Are Now, Where We Are Headed. ACTFL, 2015, 153-174.

Lumley, E., Coetzee, M., Tladinyane, R., \& Ferreira, N. (2011). Exploring the job satisfaction and organisational commitment of employees in the information technology environment. Southern African Business Review, 15(1), 100118.

Meyer, J. P., Allen, N. J., \& Smith, C. A. (1993). Commitment to organizations and occupations: Extension and test of a three-component conceptualization. Journal of applied psychology, 78(4), 538.

Meyer, J. P., Stanley, D. J., Herscovitch, L., \& Topolnytsky, L. (2002). Affective, continuance, and normative commitment to the organization: A meta-analysis of antecedents, correlates, and consequences. Journal of vocational behavior, 61(1), 20-52.

Miller, S. H. \& Green, S (2012). Incorporating Meditation as a Professional Skill within the Business Curriculum: Theory, Attitudes and Application. Global Journal of Management And Business Research, 12(3), 1-8.

Moran, P. R. (1996). "I'm not typical”: Stories of becoming a Spanish teacher. In D. Freeman \& J. C. Richards (Eds.), Teacher learning in language teaching (pp. 125-153). Cambridge: Cambridge University Press.

Motallebzadeh, K. (2005). Technology in teacher education: Developing online teacher education programs. Profile Issues in Teachers Professional Development (6), 171-175.

Nasir, M. (2011). A Comparative Study Of Contractual And Regular Teacher's Professional Attitude Towards Job Satisfaction And Job Performance (Doctoral dissertation). University of Education, Lahore.

O’Connell, T., Freed, G., \& Rothberg, M. (2010). Using Apple technology to support learning for students with sensory and learning disabilities. WGBH Educational Foundation.

Ololube, N. P. (2006). Teachers Job Satisfaction and Motivation for School Effectiveness: An Assessment. University of Helsinki, Finland.

Park, C. N., \& Son, J.-B. (2009). Implementing computer-assisted language learning in the EFL classroom: Teachers' perceptions and perspectives. International Journal of Pedagogies and Learning, 5(2), 80-101.

Rahimi, M., \& Yadollahi, S. (2011). ICT use in EFL classes: A focus on EFL teachers' characteristics. World Journal of English Language, 1(2), 17-29. doi:10.5430/wjel.v1n2p17

Richards, J. C., \& Schmidt, R. W. (2002). Longman dictionary of language teaching and applied linguistics (Third ed.): Pearson Education

Saleh Mahdi, H. (2014). The impact of Computer-Mediated Communication environments on foreign Language learning: A review of the literature. World Journal of English Language, 4(1), 9-19.

Son, J.-B. (2004). Teacher development in e-learning environments. In J.-B. Son (Ed.), Computer-assisted language learning: Concepts, contexts and practices. 107-122, Lincoln, NE: iUniverse.

Son, J.-B., Robb, T., \& Charismiadji, I. (2011). Computer literacy and competency: A survey of Indonesian teachers of English as a foreign language. CALL-EJ, 12(1), 26-42.

Varghese, M. (2010). Professional development as a site for the conceptualization and negotiation of bilingual teacher identities. Research and Practice in Language Teacher Education. Selected Papers from the First International Conference on Language Teacher Education. 193-212.

Vesanto, A. (2011). The professional identity of teachers of English (Master's thesis). University of Jyväskylä, Department of Languages English.

Warschauer, M., \& Healey, D. (1998). Computers and language learning: An overview. Language teaching, 31(02), 5771.

Woodrow, J. E. (1992). The influence of programming training on the computer literacy and attitudes of preservice teachers. Journal of Research on Computing in Education, 25(2), 200-219. 